\title{
RETROSPECTIVE STUDY OF MALARIA PREVALENCE AND Anopheles GENUS IN THE AREA OF INFLUENCE OF THE BINATIONAL ITAIPU RESERVOIR
}

\author{
Ana Lucia FALAVIGNA-GUILHERME(1), Allan Martins da SILVA(2), Edson Valdemar GUILHERME(3) \& Dina Lúcia MORAIS(1)
}

\begin{abstract}
SUMMARY
The importance of hydroelectric dams beside the human interchange in the maintenance of malarious foci and the occurrence of the Anopheles genus on the Binational Itaipu Reservoir were the main points of this retrospective study. Data were collected from existing registrations at National, State and Municipal Health Departments and literature systematic overview, from January 1984 to December 2003. The occurrence of some outbreak of malaria, mainly by Plasmodium vivax, and the prevalence of species of the Anopheles genus different from Anopheles darlingi in the region are discussed. The malaria in the left bank of Paraná River is a focal problem, which must be approached locally through health, educational and social actions to prevent the continuity of outbreaks in the area. Concomitantly, it is necessary to plan and apply effective surveillance measures in the influence area of the Itaipu Reservoir.
\end{abstract}

KEYWORDS: Malaria; Anopheles; Plasmodium vivax; Binational Itaipu Reservoir.

\section{INTRODUCTION}

In Brazil, annual cases of malaria have fluctuated around 500 thousand since $1990^{19}$. The Legal Amazon Region is responsible for $99 \%$ of those cases $^{14}$. For the other regions and states, recorded cases are nearly always imported from the Amazon region or from other countries where vectorial transmission is occuring ${ }^{14}$. Paraná, São Paulo and Mato Grosso do Sul are states that receive greater number of cases "exported" from the northern region of the country ${ }^{2}$. The migrations between the west of Paraná and the Brazilian Amazon and the pendular movements of the population between the west of Paraná and Paraguay facilitate the continual reintroduction of the etiologic agent and the occurrence of autochthonous cases of malaria in the area of influence of the Itaipu Reservoir ${ }^{8}$.

Before the beginning of the construction of the Hydroelectric of Itaipu the flow of people between the west of Paraná and the Paraguay territory was moderate, with focus on the activities of tourism and business. With the shutting of the Itaipu Dam in October 1982, Sete Quedas Falls disappeared, facilitating the interchange of people ${ }^{8}$. After that the frequency of migration between the two countries, Brazil and Paraguay, risen. Mainly needy people of low income as well as an input of dam workers were coming from other parts of Brazil ${ }^{6}$. We also have to consider that from the 70s, with the colonization of Legal Amazon, there was an intense migratory exodus of the population of Paraná, among them ex-land owners and rural employees from expropriated land for the construction of Itaipu Reservoir, towards the northern and center-western regions of Brazil ${ }^{1}$.

Regarding the Anopheles (Nyssorhynchus) darlingi, the main vector of malaria in Brazil, after the malaria outbreak occurred in 1950 in the area from the Paranapanema River to the mouth of the Paraná River, the species was found in all of the riverine locations investigated ${ }^{15}$. After the interruption of the transmission of the malaria between the 1960s and 70s, Paraná State was considered an area of low malaria risk. In 1974, the "Superintendência de Campanhas de Saúde Pública - SUCAM" (a State Department to control endemic diseases) elaborated a program of preventive activities for reducing the reintroduction risk of malaria in Guaíra, Marechal Cândido Rondon, Santa Helena, São Miguel do Iguaçu and Foz do Iguaçu, which are municipalities located in the western region of the state under influence of the Itaipu Reservoir (Fig. 1), corresponding to $7,000 \mathrm{~km}^{(3)}$. Nowadays, despite the stability of the biggest part of the population, the existence of infra-structure of housing and the predominance of secondary species of Anopheles, this area conserves the malarious potential which brings around sporadic transmission in restricted $\operatorname{areas}^{18}$.

The aim of this work was to carry out a retrospective study of human malaria cases and the occurrence of Anopheles genus mosquitoes on the impact area of the Binational Itaipu Reservoir, left margin of the Paraná River. 


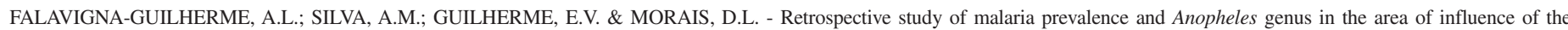
binational Itaipu reservoir. Rev. Inst. Med. trop. S. Paulo, 47(2):81-86, 2005.

\section{MATERIAL AND METHODS}

Study area: The studied municipalities are located in Western region of Paraná State, area of influence of the Itaipu Reservoir, in the left bank of the Medium Paraná River (Fig. 1). Being part of the third plateau of the Paraná State, the study area belongs to the geomorphologic unit of the central plateau of the Paraná Basin (CD Weather Maps of Paraná). The reservoir comprises the municipalities from Guaíra to Foz do Iguaçu, occupying an area of $180 \mathrm{~km}{ }^{(8)}$. Foz do Iguaçu, the most populous municipality, has 251,000 inhabitants. The region presents declivity on the east to west direction with average quotas from 100 to $300 \mathrm{~m}$. The towns of Foz do Iguaçu, Santa Helena, Santa Terezinha do Itaipu and Guairá, present the altitude of 164, 258, 218 and 220 m, respectively. In the Indian Settlement of Ocoi, São Miguel do Iguaçu town, in the vicinity of Itaipu Reservoir margin, the average altitude is $113 \mathrm{~m}$.

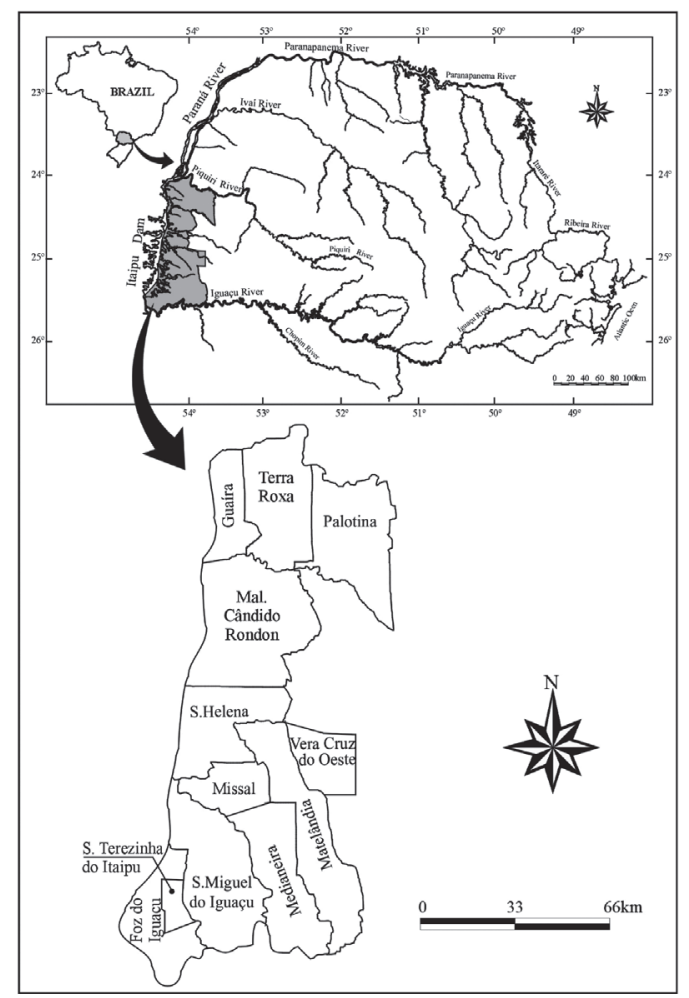

Fig. 1 - Location of the municipalities in the left bank of the Medium Paraná River and of the Itaipu Binational Reservoir Hydroelectric Dam.

The areas now occupied by the Itaipu Reservoir were covered by primitive forests in 1960 . The dam is located $16 \mathrm{~km}$ upstream of the Iguaçu River. Closed in October 1982, it has reached the normal quota of operation in 1984. After the damming, the level of the water was elevated from 100 to $220 \mathrm{~m}$ above the sea level ${ }^{8}$.

Study outline: This work was based on a retrospective study of human malaria cases and of the occurrence of Anopheles genus mosquitoes on the left margin of the Paraná River, impacted area of the Binational Itaipu Reservoir, after the formation of the reservoir. The study period was from January 1984 to December 2003.
Data collection: Data of malaria were collected from existing registrations at National Health Foundation (FUNASA) of Paraná, Municipal Health Departments, Paraná State Health Department and literature.

Data of the Anopheles genus utilized came from a literature systematic overview.

\section{RESULTS}

From the shutting of the dam until 1985, human malaria autochthonous cases in the medium Paraná River were nearly nonexistent, but the number of imported cases was around 10,000/year. Since then, the registrations show an increase of autochthonous human malaria cases in the region, reaching 1,213 autochthonous cases and 16,543 imported cases in 1989 (Fig. 2).

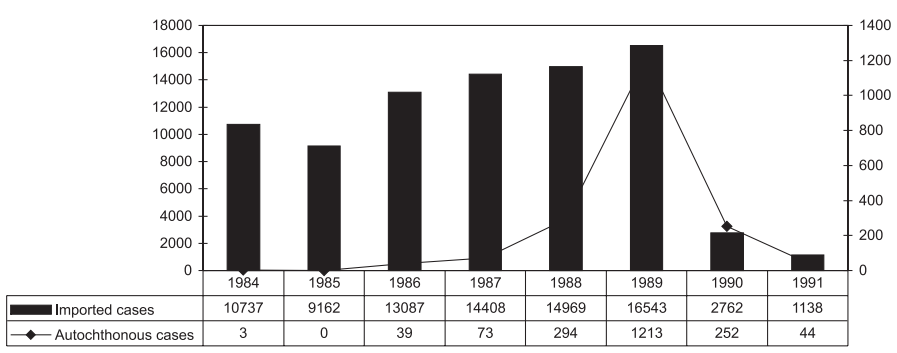

Source: FUNASA/Itaipu Binational Medical Entomology Laboratory

Fig. 2 - Autochthonous and imported cases of malaria diagnosed in western Paraná, area of influence of the Itaipu Reservoir, from 1984 to 1991.

The autochthonous cases of malaria registered in that region in 1986 were 29 in Foz do Iguaçu, nine in São Miguel do Iguaçu and one in Santa Helena ${ }^{8}$. In 1988, 83\% of them occurred in the municipalities of Foz do Iguaçu, Santa Terezinha do Itaipu and São Miguel do Iguaçu. Starting on February 1989, the epidemic outbreak of malaria emerged mainly in Foz do Iguaçu and São Miguel do Iguaçu, involving 706 and 205 annual cases ${ }^{13}$, respectively, with $97.4 \%$ of Plasmodium vixax and $2.6 \%$ of Plasmodium falciparum ${ }^{8}$.

From 1984 up to 1988 the months of greatest number of malaria cases were March and May ${ }^{5,8}$. In 1989, it happened mainly in the months of March, April and November, although autochthonous cases of malaria occurred throughout the year ${ }^{8}$.

In 1990, 252 autochthonous cases of malaria were still registered in the area of influence of Itaipu (Fig. 2). From these, 192 (76.2\%) occurred between January and May, and the municipalities mostly involved were Foz do Iguaçu, Santa Helena, Guaíra, and São Miguel do Iguaçu. The municipality of Guaíra, that had presented four cases in 1989, registered 39 in 1990, seven of which were caused by Plasmodium falciparam ${ }^{8}$. The reduction of the malaria cases in the region occurred at the same time that the diseased people were treated through FUNASA - National Health Foundation - (FUNASA, 2001) following therapeutic programmes recommended by the Health Department (Bilio). From 1989 to 1994, the combat to the vector was accomplished by semi-annual sprinkling of every house located as far 


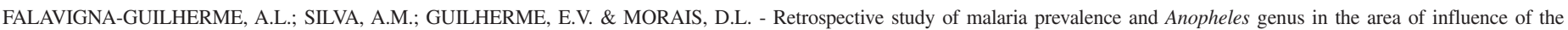
binational Itaipu reservoir. Rev. Inst. Med. trop. S. Paulo, 47(2):81-86, 2005.

as 5,000 $\mathrm{m}$ from the margin of Itaipu lake, reaching the urban areas of Foz do Iguaçu, Santa Terezinha do Itaipu, Santa Helena and Guaíra.

In 1995, 1999, 2000 and 2002 the number of autochthonous cases rose to more than one hundred (Fig. 3) equating with the adding up of imported cases from other states and Paraguay. In 1995 the autochthonous cases happened mainly in Foz do Iguaçu and Santa Terezinha do Itaipu while from 1996 to 1999, they were registered mostly in Foz do Iguaçu and in the years 2000 to 2002, in São Miguel do Iguaçu. From January 1997 to December 2002, all of the autochthonous cases diagnosed in the region were of Plasmodium vivax ${ }^{21}$.

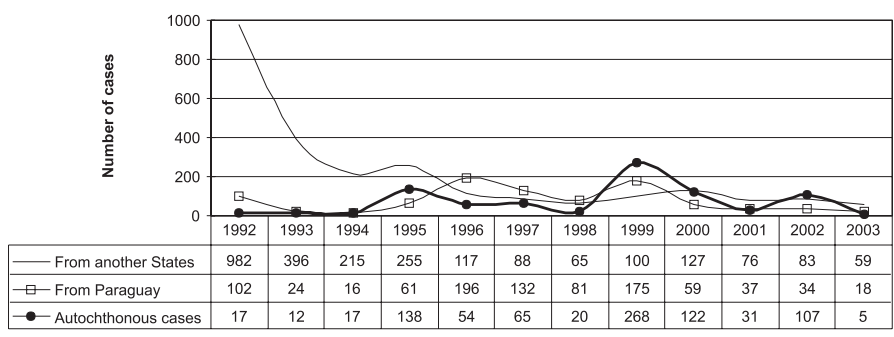

Source: FUNASA/SESA/CSA/DCDTV

Fig. 3 - Autochthonous and imported cases origin of malaria diagnosed in western Paraná, area of Influence of the Itaipu Reservoir, from 1992 to December 2003.

The imported cases of malaria in the area of influence of Itaipu came as much from the other Brazilian states (Legal Amazon) as from Paraguay (Fig. 3). During the years from 1992 to 1995, 2001 and 2003 prevailed the number of imported cases from other states whereas from 1996 to 1998, most imported cases came from Paraguay (Fig. 3).

In relation to the species of Anopheles found in the region of influence of the Binational Itaipu Reservoir, the occurrence of $A n$. darling $i$ was registered in almost the whole period investigated except between 1994 and 1997 in punctiform data collection ${ }^{10,11}$. In general, this species have always presented a low prevalence in relation to the others, except in periods of outbreak, where the prevalence had been higher than $10 \% \%^{9,13}$ (Table 1). The predominant species in that region were An. albitarsis, An. evansae, An. argyritarsis and An. galvaoi. The species An. albitarsis and An. galvaoi were prevalent in collections realized near the Itaipu Reservoir including human baits ${ }^{17}$.

The autochthonous cases of malaria in the investigated area, in the period from 2000 to 2003, occurred mainly in the Indian Settlement of Ocoi, located in São Miguel do Iguaçu and in inhabitants of Foz do Iguaçu, Santa Helena and Santa Terezinha do Itaipu. In almost every age group, individuals of the masculine sex were the most attacked (Table 2). As for the occupation, excluding the indigenous population, 23 professional categories were found, and the most reported ones were farmer, housewife, mason and fishermen. Such data confirm that there was transmission in the reported period, as much in outdoors as in indoors, with no clear delimitation between the semi-rural and rural areas.

\section{DISCUSSION}

The area where the Itaipu reservoir is situated, the region of the medium Paraná river, has passed through several phytogeographical and ecological changes. From 1968 to 1982 its waters normally had a great outgo, which flew through steep slopes of more than $100 \mathrm{~m}^{(4)}$. After the construction of the reservoir the waters became less turbulent facilitating the formation of marshes and backwaters, ideal for the installation of Anopheles breeding places ${ }^{5}$. Modification in the climate, especially as for the greater level of humidity, can have also influenced in the proliferation of the Anopheles ${ }^{8}$. These facts combined with the intense flow of incoming people from endemic areas, were responsible for the dozens of imported and autochthonous cases of malaria annually registered in the Itaipu area ${ }^{17,18}$.

Before the construction of the reservoir there was sporadic registrations of malaria mainly in the period from February to June, subsequent to the great floods in the area between Guaíra and Foz do Iguaçu ${ }^{4}$. However, in the Upper Paraná River, area between Guaíra and São Paulo state, the malaria occurred in epidemic outbreaks ${ }^{15}$. At this same area, the Anopheles' density, especially of An. darlingi, was higher than in the area of the Medium Paraná River. With the shutting of the Itaipu dam and the maintenance of the breeding places for $A n$. darlingi it was expected to have had an expressive number of cases of malaria especially in the Upper Paraná River ${ }^{5}$. The adoption of satisfactory preventive measures has supported the low incidence of malaria in that region following the normal pattern ${ }^{5}$. Whereas in the low part of the Medium Paraná River, where the density of An. darlingi began increasing only after $1983^{5}$, cases of autochthonous malaria were registered especially in the municipalities of Foz do Iguaçu, Santa Terezinha do Itaipu and São Miguel do Iguaçu ${ }^{16}$. In 1986 the autochthonous malaria was registered in Foz do Iguaçu, firstly in urban population nuclei of medium and low income like those situated in the areas close to where the Itaipu Reservoir was built ${ }^{8}$. It is important to mention that this municipality is far from the region of Guaíra (Fig. 1) where the cases of malaria initially predominated. In the cold months, June and July, and the months of low relative humidity, August and September, there was interruption of the transmission due to the low density of the vector ${ }^{8}$.

From 1986 onwards, cases of autochthonous malaria in the area of Medium Paraná River began to rise, reaching a sharp point in 1989 (Fig. 2). This picture could be explained by the introduction of abundant infection sources of imported cases into the area (gametophorous) ${ }^{5}$, as well as the presence of An. darlingi $i^{5}$. As this species have not always been present in the area studied (Table 1), it also suggests the involvement of other species in the transmission of malaria as $A n$. albitarsis and $A n$. galvaoi ${ }^{10,20}$ that had showed especially attracted by human baits ${ }^{10}$. An. evansae and An. darlingi were collected through human baits inside home and An. argyritarsis outside home ${ }^{7}$. It is important to mention that secondary species like An. albitarsis, An. aquasalis, An. cruzii and An. bellator, have always predominated in malarious areas where An. darlingi could be also found ${ }^{12}$. The outstanding presence of An. albitarsis sensu latu in collections carried out in the town of Guaíra, with human baits and Shannon trap, suggests its indication as a possible participant in the epidemiological chart of malaria in the region ${ }^{10,20}$. The control of the outbreak in mid 1990 was due to the sprinkling insecticide carried out by FUNASA, done especially in the cold or dry months (May to September), besides the treatment of the infected individuals ${ }^{8}$. 


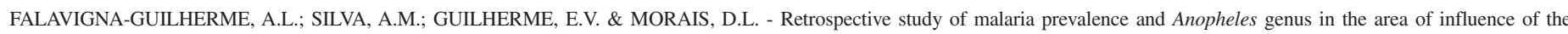
binational Itaipu reservoir. Rev. Inst. Med. trop. S. Paulo, 47(2):81-86, 2005.

Table 1

Anopheles species in the left bank of the Binational Itaipu Reservoir according to the literature, from 1978 to 2003

\begin{tabular}{|c|c|c|c|c|c|}
\hline Investigation period & Region or Municipality & Species & $\begin{array}{l}\text { Prevalence } \\
\quad(\%)\end{array}$ & $\begin{array}{l}\text { Total number } \\
\text { of Anopheles }\end{array}$ & Type of collection \\
\hline $\mathrm{Jan} / 78-\mathrm{Mar} / 85^{5}$ & $\begin{array}{l}\text { Foz do Iguaçu } \\
\text { Terra Roxa } \\
\text { Guaíra } \\
\text { Mal. Cândido Rondon } \\
\text { Santa Helena } \\
\text { S. Miguel do Iguaçu }\end{array}$ & An. darlingi & - & Non mentioned & Human bait near the forest \\
\hline Jan/89 - Dec/89 & $\begin{array}{l}\text { Foz do Iguaçu } \\
\text { Terra Roxa } \\
\text { Guaíra } \\
\text { Mal. Cândido Rondon } \\
\text { Santa Helena } \\
\text { S. Miguel do Iguaçu }\end{array}$ & $\begin{array}{l}\text { An. albitarsis } \\
\text { An. evansae } \\
\text { An. darlingi }\end{array}$ & $\begin{array}{l}47.5 \\
27.8 \\
11.5\end{array}$ & 4,247 & $\begin{array}{l}\text { Human bait domicile and } \\
\text { extradomicile }\end{array}$ \\
\hline Jan/89 - Dec/89 13 & $\begin{array}{l}\text { Foz do Iguaçu } \\
\text { Terra Roxa } \\
\text { Guaíra } \\
\text { Mal. Cândido Rondon } \\
\text { Santa Helena } \\
\text { S. Miguel do Iguaçu }\end{array}$ & $\begin{array}{l}\text { An. evansae } \\
\text { An. albitarsis } \\
\text { An. darlingi }\end{array}$ & $\begin{array}{c}48.4 \\
33.3 \\
2.6\end{array}$ & 2,500 & $\begin{array}{l}\text { Trap (immature stages) } \\
\text { border of Paraná river }\end{array}$ \\
\hline Jan/91 - Dec/9120 & Guaíra & An. darlingi & - & 01 & $\begin{array}{l}\text { Human bait extradomicile- } \\
\text { urban area }\end{array}$ \\
\hline Nov/94 - Aug/95 & Guaíra & $\begin{array}{l}\text { An. albitarsis } \\
\text { An. galvaoi } \\
\text { An. evansae }\end{array}$ & $\begin{array}{c}61.7 \\
35.2 \\
1.3\end{array}$ & 6,973 & $\begin{array}{l}\text { Human bait Shannon trap } \\
\text { forest of Itaipu Reservoir }\end{array}$ \\
\hline Jan/96 - Dec/97 ${ }^{11}$ & Foz do Iguaçu & $\begin{array}{l}\text { An. albitarsis } \\
\text { An. galvaoi } \\
\text { An. mediopunctatus } \\
\text { An. evansae } \\
\text { An. lutzii } \\
\text { An. fluminensis }\end{array}$ & $\begin{array}{l}30.9 \\
20.7 \\
10.2 \\
9.7 \\
8.4 \\
6.9\end{array}$ & 3,019 & $\begin{array}{l}\text { Human bait Shannon trap } \\
\text { Iguaçu National Park }\end{array}$ \\
\hline Aug/97 - Dec/977 & $\begin{array}{l}\text { S. Terezinha do Iguaçu } \\
\text { S. Miguel do Iguaçu } \\
\text { Missal } \\
\text { Santa Helena }\end{array}$ & $\begin{array}{l}\text { An. galvaoi } \\
\text { An. evansae } \\
\text { An. oswaldoi } \\
\text { An. lutzii } \\
\text { An. darlingi }\end{array}$ & $\begin{array}{l}28.5 \\
26.3 \\
10.2 \\
9.5 \\
5.8\end{array}$ & Non mentioned & $\begin{array}{l}\text { Human bait Shannon trap } \\
\text { domicile, extradomicile, } \\
\text { Forest border - Iguaçu } \\
\text { National Park }\end{array}$ \\
\hline Oct/97 - Oct/999 & Guaíra to Foz do Iguaçu & $\begin{array}{l}\text { An. evansae } \\
\text { An. argyritarsis } \\
\text { An. darlingi } \\
\text { An. lutzii } \\
\text { An. strodei } \\
\text { An. parvus } \\
\text { An. galvaoi } \\
\text { An. albitarsis }\end{array}$ & $\begin{array}{c}21.9 \\
15.7 \\
15.4 \\
10.0 \\
9.8 \\
9.6 \\
8.0 \\
4.6\end{array}$ & 8,408 & $\begin{array}{l}\text { Human bait Shannon trap } \\
\text { domicile, peridomicile } \\
\text { Forest border and interior } \\
\text { Area of influence of } \\
\text { Itaipu reservoir }\end{array}$ \\
\hline Oct/97 - Nov/00 17 & São Miguel do Iguaçu & $\begin{array}{l}\text { An. evansae } \\
\text { An. argyritarsis } \\
\text { An. lutzii } \\
\text { An. parvus } \\
\text { An. strodei } \\
\text { An. albitarsis } \\
\text { An. galvaoi } \\
\text { An. darlingi }\end{array}$ & $\begin{array}{l}22.3 \\
21.3 \\
12.1 \\
10.1 \\
9.4 \\
9.1 \\
5.6 \\
4.4\end{array}$ & 5,322 & $\begin{array}{l}\text { Human bait Shannon trap } \\
\text { domicile, Forest border } \\
\text { Indian settlement }\end{array}$ \\
\hline Jan/00 - Dec/016 & São Miguel do Iguaçu & $\begin{array}{l}\text { An. argyritarsis } \\
\text { An. albitarsis } \\
\text { An. evansae } \\
\text { An. lutzii } \\
\text { An. parvus }\end{array}$ & $\begin{array}{l}43.8 \\
21.5 \\
11.2 \\
11.2 \\
7.4\end{array}$ & 162 & $\begin{array}{l}\text { Human bait Shannon trap } \\
\text { domicile, Forest border } \\
\text { Indian settlement }\end{array}$ \\
\hline
\end{tabular}




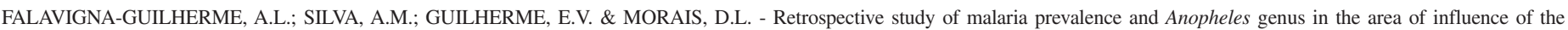
binational Itaipu reservoir. Rev. Inst. Med. trop. S. Paulo, 47(2):81-86, 2005.

Table 2

Distribution of autochthonous cases by age, sex and Indigenous population in the left bank of the Binational Itaipu Reservoir, from 2000 to 2003

\begin{tabular}{lccccc}
\hline \multirow{2}{*}{ Age (years) } & \multicolumn{2}{c}{ Sex } & \multicolumn{2}{c}{ Indigenous population } & Total \\
& Male & Female & Number & $\%$ & \\
\hline$\leq 7$ & 32 & 23 & 47 & 85.4 & 55 \\
$\geq 8-14$ & 30 & 18 & 36 & 75.0 & 48 \\
$\geq 15-22$ & 27 & 08 & 22 & 62.9 & 35 \\
$\geq 23-30$ & 07 & 11 & 08 & 44.4 & 18 \\
$>30$ & 71 & 38 & 33 & 30.3 & 109 \\
Total & 167 & 98 & 146 & 55.1 & 265 \\
\hline
\end{tabular}

The western region of Paraná State is considered to be an area of low risk in the transmission of malaria ${ }^{9}$, and since 1997 all the autochthonous cases were $P$. vivax. However, due to the vulnerability of the area of Itaipu Reservoir, the number of autochthonous cases of malaria can vary presenting sudden increase like the ones in the years of 1995, 1999, 2000 and 2002 (Fig. 3). Such situation was due to the constant presence of imported cases from Paraguay and the lack of jobs and professionalization also forces many workers to leave their homes and families and migrate to the Amazon Brazilian pioneering fronts, only returning at the end of the year time which corresponds to the rainy summer period that facilitates the Anopheles breeding places. In this way if they contracted the malaria infection they could serve as infection sources for Anopheles when they returned to Itaipu Reservoir region. After 1994, the cycles of sprinkling insecticide in the urban areas were interrupted, being restricted to the locations where outbreaks emerge. Such policy gave chance to the occurrence of malaria cases in the settlement of Ocoi, São Miguel do Iguaçu, between 2000 and 2002. The collection of mosquitoes or anophelines were not conducted in a systematic way and not always in periods of transmission of malaria, what made difficult the correlation between the cases of malaria and the species of Anopheles in the investigated region. Besides, during all these years, the presence of An. albitarsis, An. evansae, An. galvanoi and $A n$. argyritarsis was observed (Table 1). In relation to An. darlingi, not all papers have reported its finding (Table 1), although there is not in literature continuous data from long term collection, in different strategic points, with standardization of the types of traps and the sampled points. It is necessary to increase the entomological knowledge in the area of the Itaipu Reservoir to serve as parameter in the measures of selective control of the vector for the prevention of the epidemic outbreaks ${ }^{9,16}$.

The municipalities of Foz do Iguaçu, Santa Terezinha do Itaipu, Guaíra and Santa Helena and the indigenous area of São Miguel do Iguaçu (Ocoi Indian Settlement) are considered by the FUNASA technicians as areas of high risk of malaria contamination. In other words, their very high vulnerability, that is, conditions which facilitate the installation of Anopheles breeding places, is due to the fact that they lie within a belt of 5,000 m starting from the left margin of the Reservoir and extending to the banks of the Paraná and Iguaçu rivers, descending to an altitude of $260 \mathrm{~m}$, varying from 113 to $258 \mathrm{~m}{ }^{(8)}$. It must be emphasized that in the rainy months, from October to January, the high temperature and the humidity facilitate the installation of vector breeding places. It is still necessary to consider the touristic importance of Foz do
Iguaçu, Guaíra and Santa Helena which attracts annually for that region a great number of people from different parts of Brazil and the world.

It must be emphasized that a rigorous control in the area of Itaipu is necessary, since this reservoir is the main mediate cause of $A n$. darlingi proliferation, another species of Anopheles and of mosquitoes that could be responsible for arboviroses ${ }^{5,20}$. Some control measures could undoubtedly reduce the breeding and avoid the autochthonous cases. The appropriate operation in connection with the levels of water of the reservoir should be tried to prevent the formation of swamps, the accumulation of stagnant waters along the edges of the dam, and the excesses of floating aquatic vegetation dispersion in various areas of Brazil. Malaria in the left bank of Paraná River is a focal problem. It must be approached locally with constant search for patients with prone to have malaria, providing early diagnosis, immediate treatment, cure control, development of educational actions and social mobilization to prevent the continuity of the epidemic outbreaks in the area. Concomitantly, it is necessary to plan and apply effective surveillance measures in the area of the Itaipu Reservoir.

\section{RESUMO}

\section{Estudo retrospectivo da prevalência de malária e do gênero Anopheles na área de influência do reservatório de Itaipu Binacional}

A importância de reservatórios de hidroelétricas e do intercâmbio humano na manutenção de focos de malária e a ocorrência do gênero Anopheles no reservatório de Itaipu Binacional foram os pontos destacados neste estudo retrospectivo. Os dados foram coletados de registros existentes em órgãos municipais, estadual e nacional de saúde e por revisão sistemática da literatura, no período de janeiro de 1984 a dezembro de 2003. A ocorrência de alguns surtos de malária, principalmente por Plasmodium vivax, e a prevalência de espécies do gênero Anopheles diferentes de Anopheles darlingi na região foram discutidos. A malária na margem esquerda do rio Paraná é um problema focal que deve ser abordado localmente através de medidas voltadas à saúde, educação e área social que previnam a continuidade da ocorrência de surtos na área. Concomitantemente, é necessário planejar e aplicar medidas efetivas de vigilância epidemiológica na área de influência do reservatório de Itaipu.

\section{ACKNOWLEDGEMENTS}

We are grateful to Lúcia H. Minami, Coordinator of Malaria Service in Paraná State Health Department (former SUCAM) for her assistance in data information. We are specially grateful to Dr. Ênio Luz, Professor of the Federal Paraná University for literary data.

\section{REFERENCES}

1. ALEGRE, M. \& MORO, D.A. - A mobilidade da população nas antigas áreas cafeeiras do norte do Paraná. Bol. Geografia (UEM), 1: 28-73, 1986.

2. BARATA, R.C.B. - Malária no Brasil: panorama epidemiológico na última década. Cadern. Saúde públ. (Rio de J.), 11: 128-136, 1995.

3. BRASIL. Ministério da Saúde. SUCAM-PR - Controle das grandes endemias. Requisitado pelo projeto Itaipu; relato de Ênio Luz. Brasília, 1987. 


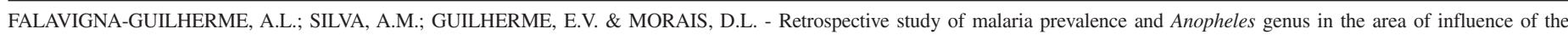
binational Itaipu reservoir. Rev. Inst. Med. trop. S. Paulo, 47(2):81-86, 2005.

4. CONSOLIM, J. \& GALVÃO, J.T. - Sobre os anofelinos do rio Paraná. I. Densidade e regime do rio. Arq. Biol. Tecnol., 16: 174-181, 1973.

5. CONSOliM, J.; LUZ, E.; PELlEGRINI, N. \& TORRES, P.B. - O Anopheles (Nyssorhynchus) darlingi Root, 1926 e a malária no lago de Itaipu, Estado do Paraná, Brasil: uma revisão de dados. Arq. Biol. Tecnol., 34: 263-286, 1991.

6. CURADO, I.; DUARTE, A.M.R.C.; LAL, A.A.; OLIVEIRA, S.G. \& KLOETZEL, J.K. Antibodies anti bloodstream and circumsporozoite antigens (Plasmodium vivax and Plasmodium malariae/P. brasilianum) in areas of very low malaria endemicity in Brazil. Mem. Inst. Oswaldo Cruz, 92: 235-243, 1997.

7. FERREIRA, A.C.; FERREIRA, R.; GOULART, S.F. et al. - Nota preliminar da coleta de mosquitos do gênero Anopheles (Diptera, Culicidae) na região do lago de Itaipu, Paraná, Brasil. In: SEMINÁRIO NACIONAL DE ZOONOSES E ANIMAIS PEÇONHENTOS, 3., Guarapari, 1998. Anais. p. 126.

8. FERREIRA, M.E.M.C. - Ocorrência de malária na área de influência do reservatório de Itaipu - margem esquerda - Paraná, Brasil. Um estudo de geografia médica. São Paulo, 1996. (Tese de doutoramento - Faculdade de Filosofia, Letras e Ciências Humanas da Universidade de São Paulo).

9. GOULART, S.F.; FERREIRA, A.C.; MOURA, S.M. et al. - Anofelinos (Diptera: Culicidae) - na área de influência do lago de Itaipu - oeste do Paraná. Rev. Soc. bras. Med. trop., 33 (supl. 1): 417, 2000.

10. GUIMARÃES, A.E.; MELLO, R.P.; LOPES, C.M. et al. - Prevalência de anofelinos (Diptera: Culicidae) no crepúsculo vespertino em áreas da usina hidrelétrica de Itaipu, no município de Guaíra, Estado do Paraná, Brasil. Mem. Inst. Oswaldo Cruz, 92: 745-754, 1997.

11. GUIMARÃES, A.E.; LOPES, C.M.; MELLO, R.P. \& ALENCAR, J. - Ecologia de mosquitos (Diptera, Culicidae) em áreas do Parque Nacional do Iguaçu, Brasil. 1. Distribuição por habitat. Cadern. Saúde públ. (Rio de J.), 19: 1107-1116, 2003.

12. LOIOLA, C.C.P.; SILVA, C.J.M. \& TAUIL, P.L. - Controle da malária no Brasil: 1965 a 2001. Pan Amer. J. publ. Hlth, 11: 235-244, 2002.
13. LUZ, E.; TOMICHI, G.; NAZARENO, N.R.X. \& CAROLLO, C.F.N. - Reintrodução da malária na área de influência do lago de Itaipu-Paraná, Brasil. In: Ministério da Saúde. SUCAM. Paraná. Relatório técnico interno do Departamento de Malária do Paraná. Curitiba, 1989.

14. MINISTÉRIO DA SAÚDE. Secretaria de Vigilância em Saúde - Saúde Brasil 2004 uma análise. 365 p. Accessed in: 19 July 2004. Available at: <http:// dtr2001.saude.gov.br/svs/pub/saude_brasil_2004/saude_brasil_2004.pdf >

15. RACHOU, R.G.; LOBO, A.G.S. \& LUZ, E. - Dispersão do Anopheles (N.) darlingi no recrudescimento epidêmico de malária em 1950 no norte do Paraná. Rev. bras. Malar., 6: 411-414, 1954.

16. SESA (Secretaria de Estado da Saúde), 2003. Bol. Epidem. Saúde no Paraná, Jan.June 2003. <http://www.saude.pr.gov.br/Boletim_Epidemiologico/>.Malária, dengue e febre amarela

17. SILVA, A.M. - Um estudo sobre a malária no Paraná. Fauna anofélica (Diptera: Culicidae) da reserva indígena do Ocoí, município de São Miguel do Iguaçu, Paraná. Saúde no Paraná. Bol. Epidem. Secretaria de Saúde do Paraná, (18), January to June, 2003.

18. SILVA, A.M.; NATAL, J. \& BARATA, J.M.S. - Atualização da carta anofélica do Estado do Paraná. Rev. Soc. bras. Med. trop., 36 (supl. 1): 56, 2003.

19. SILVA, L.H.P. \& OLIVEIRA, V.E.G. - O desafio da malária: o caso brasileiro e o que se pode esperar dos progressos da era genômica. Ciênc. Saúde colet., 7: 49-63, 2002.

20. TEODORO, U.; FALAVIGNA-GUILHERME, A.L.; LOZOVEI, A.L. et al. - Culicídeos do lago de Itaipu, no rio Paraná, Sul do Brasil. Rev. Saúde públ. (S. Paulo), 29: 614, 1995.

21. TRENCH, F.G.P.; ELETÂNI, A; SILVA, C.R.S.E. et al. - Número de casos de malária em Foz do Iguaçu por 100.000 habitantes, do ano de 1997 a 2002. Rev. Soc. bras. Med. trop., 36 (supl. 1): 288, 2003.

Received: 11 February 2004

Accepted: 3 March 2005 